NBER WORKING PAPER SERIES

INTERACTIONS BETWEEN INFLATION AND

TRADE-REGIME OBJECTIVES IN STABILIZATION PROGRAMS

Anne 0. Krueger

Working Paper No. 475

NATIONAL BUREAU OF ECONOMIC RESEARCH 1050 Massachusetts Avenue

Cambridge MA 02138

May 1980

This paper was prepared for the Brookings Institution Conference on Economics Stabilization in Developing Countries, October 25-26, 1979 in Washington, DC. The research reported here is part of the NBER's research project in International Studies. Any opinions expressed are those of the author and not those of the National Bureau of Economic Research. 


\section{Interactions Between Inflation and Trade-Regime objectives in Stabilization Programs}

\section{$\triangle B S T R A C P$}

This paper examines the relationship between macroeconomic abjectives of controlling inflation and trade-regime objectives in stabilization programs of developing countries. It is seen that there need be, in principle, no close relationship between the two, as a crawling peg exchange-rate policy can prevent inflation from affecting the performance of the foreign sector. In practice, trade regime objectives have been linked with inflation-reducing objectives, often to the detriment of resource allocation and growth. Differences between devaluation under liberalized regimes and under exchange control are also examined.

Anne 0. Krueger Department of Economics 1035 Business Administration 271 19th Avenue South Minneapolis, Minnesota 55455

(612) $373-3655$ 
Table of Contents

Table of Contents. . . . . . . . . . . . . . . . 1 List of Tables...................... 2 Introduction ....................... 3 The Price-Level Exchange-Rate Trade-Regime Relationship. . . . 4 Growth under Alternative Trade Regimes. . . . . . . 8 Inflation and Growth. ................. 13 Altering the Trade Regime ............. 14 Costs of Reducing the Inflation Rate. .......... 16 Interactions between Inflation and the Trade Regime. . . . . 18 Payments Deficit. . . . . . . . . . . . . 22 Liberalizing the Trade Regime . . . . . . . . . 25 Stabilization Programs and Long-Term Development . . . . . 29 Objectives. . . . . . . . . . . . . . . 33 Preexisting Conditions. . . . . . . . . . 35 Policies. . . . . . . . . . . . . . . . 39 Trade-0ffs in Stabilization Program. . . . . . . . . . 46 Short-Run versus Long-Run . . . . . . . . . . . 46 Gradual ism versus Shock . . . . . . . . . . 48 Foreign Borrowing versus Recession. . . . . . . . 49 Implications for Donor Countries . . . . . . . . . . 50 Footnotes. . . . . . . . . . . . . . . . . 55 Bibliography ..................... 62 
List of Tables

Table 1. Characterization of Alternative Market Interactions. . 6

Table 2. Financial Programs as a Component of Stabilization

Programs, 79 Countries, 1963-72. . . . . . . . . 41 


\section{Interactions Between Inflation and Trade-Regime Objectives in Stabilization Programs}

\section{Introduction}

Examination of the relationship between macro-economic growth and the trade objectives of stabilization programs is an exceptionally difficult assignment. There are three separate bodies of relevant literature -- relating to trade regimes, to inflation and its causes and consequences, and to the determinants of economic growth -- each of which is pertinent to the analysis and each of which has numerous points of contention. This in itself makes the assignment challenging. In addition, the sorts of problems that arise with inflation, with trade and payments regimes, and with development strategies in general, are sufficiently different between countries so that no single model is appropriate for all of them.

To make the task manageable, I propose to start by setting forth a very elementary framework for analyzing the relationship between the trade regime and monetary-macro aggregates. Within this framework, it is readily seen that, in principle, the interaction between different types of inflation and the trade regimes can be minimal. The costs of altering either the anticipated rate of inflation or the nature of the trade regime, and the effects of those states and changes on economic growth, are then briefly set forth. The next section of the paper then examines the more 
prevalent case in which the authorities' efforts to contain inflation are reflected in a trade regime and real exchange rate different from that which would be chosen in the absence of the inflationary pressures, and traces the interaction between inflation and the trade regime. With that background, the next section then sets forth a classification of types of stabilization programs and analyzes the sorts of policy issues that arise in each category and their relationship to economic development. A final section examines the main trade-offs that arise in deciding on the components of a stabilization program.

The Price Level - Exchange Rate - Trade Regime Relationship

Depending on the question at hand, the appropriate model for analyzing any one of the three topics indicated in the section heading can be quite different. Detemination of the price level is a macromonetary phenomenon, although in the short run cost-push and microeconomic phenomena (such as a good harvest) can enter into its determination. In an open economy with full convertibility and no quantitative restrictions upon international transactions, the exchange rate is likely to be a monetary phenomenon as well. If, however, quantitative restrictions apply to a large number of international transactions, the exchange rate will also be an important variable in affecting two significant relative prices: that between home goods and tradable goods, and that between the domestic prices of exportables and of import-competing goods. Finally, the trade regime itself consists of 
the policies and instruments used by a country to achieve two targets, the first being the relationship between domestic prices of import-competing and exportable goods and the second, balance in transactions between residents and foreigners.

In principle, appropriate use of policy instruments can achieve total separation of the causes and consequences of the rate of price. level increase from any impact upon the trade regime. Such a circumstance is seldom found in the real world (although as will be argued the sliding peg regime can provide a fairly close approximation to it), but it is useful to establish the basic relationships. Within that context, analysis of alternative trade regimes, and their causes and consequences for economic growth, can be carried out.

Table 1 provides a schematic representation of the three markets and their relationship to trade regimes. The basic proposition underlying the analysis is that for any price level, there correspond: an exchange rate which will leave the real variables in the system unaltered. This is nothing other than an application of the dichotomy to the international arena: if all demand and supply functions are homogeneous of degree zero in prices and money income, then it follows that for any rate of increase in the money supply, there is a corresponding (and equal) proportionate appreciation or depreciation of the currency that will leave all excess demand functions in the system unaltered by the change. 1 / 
Table 1. Characterization of Alternative Market Interactions

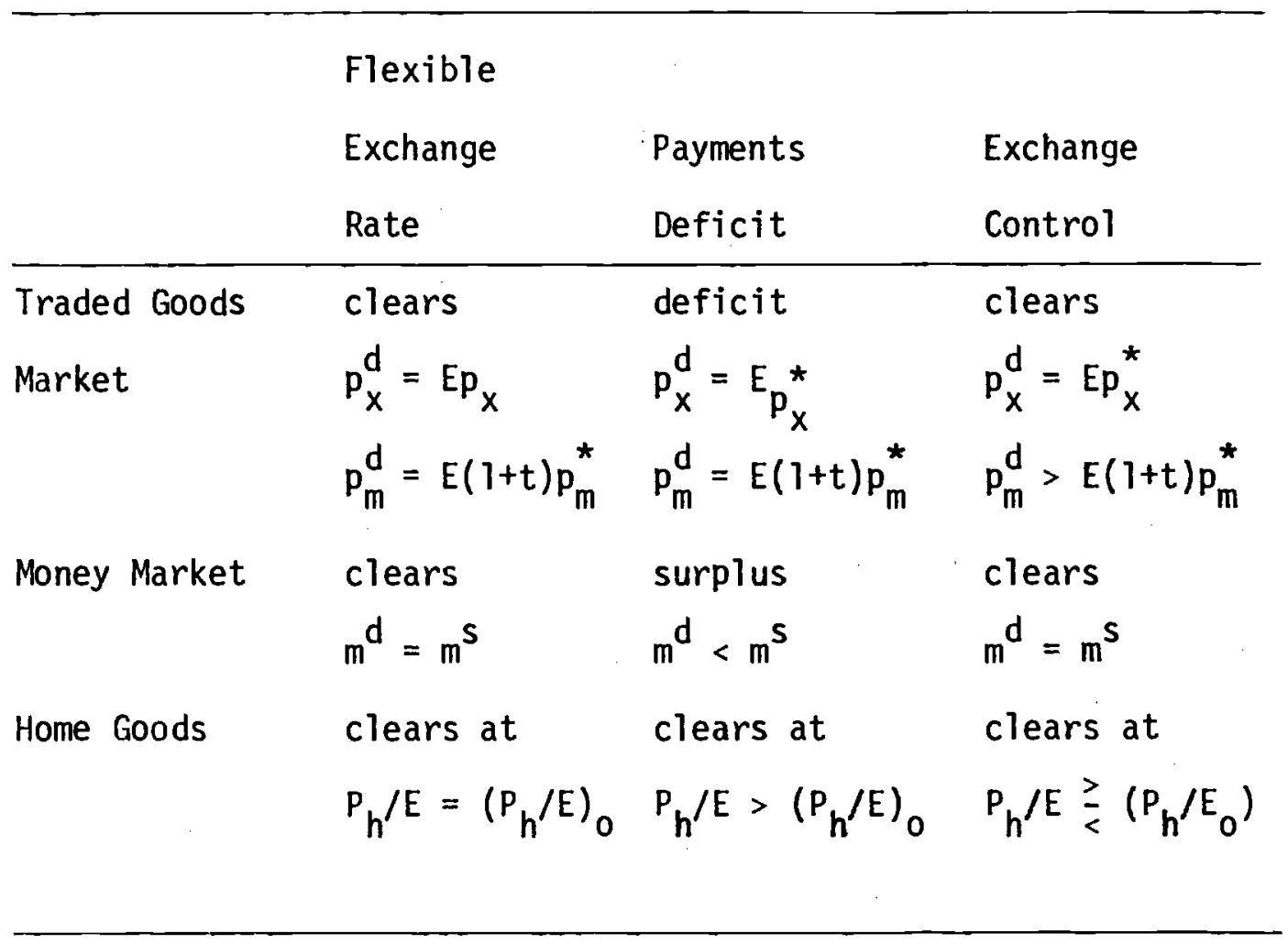


The three markets involved are traded goods, home goods, and the money market. $2 /$ Under a flexible exchange rate regime, all three markets clear with individuals free to carry out their desired transactions at prevailing prices. The traded goods market clears with the exchange rate (price of foreign exchange) $E$, equating the foreign prices of the home country's importable and exportable foreign prices of the home country's importable and exportable $\left(p_{m}^{d}\right.$ and $\left.p_{x}^{d}\right)$ with foreign prices of the same goods, denoted with an asterisk. The term $(1+t)$ is included in the import price relation to indicate that flexible exchange rates are compatible with any tariff structure and level of desired protection for import-competing industries, a point to which we shall return below. Under flexible exchange rates, the money market naturally clears, as does the market for home goods. For later reference, it is convenient to note that we have denoted the market clearing price for home goods under flexible exchange rates as $\left(p_{h} / E\right)^{0}$. This notation is useful in that the home goods market always clears: what differentiates different regimes is the relative price of home goods (and therefore their relative importance in domestic production): a higher marketclearing price for home goods corresponds to greater domestic production and, of course, consumption of those goods. 3 /

Under a flexible-rate regime, any change in the anticipated rate of inflation is reflected in a shift in the excess demand function for foreign exchange. Abstracting from short-run phenomena 
(such as $\mathrm{J}$-curve responses of exports and imports to the changed short-run price of tradable goods relative to home goods), the market for tradable goods will be unaffected in real terms.

Thus, if inflation were perfectly anticipated, the time path of the exchange rate and the domestic price level would coincide in such a way that the relative price of tradable and home goods remained stable.

To be sure, inflation is never smooth and perfectly anticipated. Under fixed exchange rates, the real exchange rate is affected, and to that attention will turn below. For present purposes, however, the central point is that there is a way in which the payments regime can be fairly well insulated from the effects of inflation: permitting or insuring that the real exchange rate is not influenced by changes in the domestic price level. 4/ For purposes of analysis, it is useful first to proceed to discuss the costs of inflation and the costs of alternative trade regimes on the assumption that inflation does not affect the real rate of exchange and that the real exchange rate does not affect the rate of inflation.

Growth under Alternative Trade Regimes

In the context of developing countries' economies, the key link between the trade regime and economic growth is the way in which the trade regime is employed in relation to the domestic growth pattern. Economic theory tells us that new resources should be allocated among tradable-goods industries in such a way that at the margin 
resources devoted to saving a dollar of foreign exchange should be the same as the marginal resources devoted to earning a dollar of foreign exchange. However, there is also a need on the part of developing countries to provide infant industry support to many of these activities. Such support can be of several kinds, but prominent among the techniques used in many developing countries has been the trade regime: it has been employed to protect domestic producers against competition from imports. Such a policy, import substitution (IS), has generally resulted implicitly or explicitly in discouragement of exports. The alternative means of encouraging growth of tradable goods industries consists of providing incentives primarily for production, in which case it usually results that a large fraction of incremental output is exported. Very often, encouragement is given to exports directly.

For a variety of reasons, most countries seem to have industrialization and trade policies that result in a significant bias toward either export promotion (EP) or. IS. The extent of bias is defined as the degree to which the ratio of the domestic prices of importables to exportables diverges from their international price ratio. Thus, using the terminology of Table 1 and assuming the appropriate aggregation across commodity categories has been performed, bias, B, can be defined as:

$$
B=\frac{p_{m}^{d}}{p_{x}^{d}} / \frac{p_{m}^{*}}{p_{x}^{*}}
$$


The greater the divergence of $B$ from unity in either direction, the more biased the regime. Bs greater than unity represent a bias toward import substitution, while those less than unity represent biases toward export promotion.

Without going into the reasons in any great detail, IS regimes tend to become increasingly biased toward IS over time as export earnings fail to grow as rapidly as demand for imports, as the exchange rate tends to be set at unrealistic levels, as the incremental value of output per unit of investment decreases with small sizes of domestic markets, and as opportunities for further IS diminish rapidly. Also, IS regimes often tend increasingly toward quantitative restrictions upon imports, and fairly detailed quantitative controls over domestic economic activity. All of these phenomena seem to result in a fairly unsatisfactory rate of economic growth for the countries undertaking the policies. A simplistic summary of experience with IS for most developing countries would be that, after opportunities for "easy" IS were exhausted, growth rates have tended to slow significantly, either secularly, or in a stop-go pattern as foreign exchange availability has determined the rate at which the economy could grow. For present purposes, it should be noted that one of the self-reinforcing phenomena with IS is that the implicit discouragement of export growth tends to increase the apparent "shortage" of foreign exchange. 
The built-in tendency for IS to decelerate as it continues may be the most important long-run growth cost of IS regimes, but there are also others that should be noted briefly. Chief among these is that IS regimes tend to promote a fairly indiscriminate pattern of industrial development. High-cost, inefficient industries develop alongside lower-cost potentially efficient ones. Even where the domestic market for the product is sufficiently large to permit efficient-size plants to be established, low-cost firms have difficulty expanding at a rate much faster than the rate of growth of domestic demand. Low-cost and high-cost firms therefore tend to expand pari passu, in part because the disincentive to export is so great that few firms can profitably do so, and in part because controls tend to set up quasi-monopoly positions for individual firms that insure maintenance of market share: allocation of rights to import scarce intermediate goods and raw materials very often rigidify individual firms' market shares. To be sure, not all of these costs of an IS regime are inevitable, as alternative means of fostering IS can have significantly different results. Nonetheless, the evidence strongly suggests significant tendencies in this direction.

Export promotion policies can also be carried out in a variety of ways, some superior to others. The reader should bear in mind that the definition of bias indicates the extent to which an EP strategy is followed: all countries have "export promotion" strategies, but in many cases those strategies are really only a means 
of offsetting some of the disincentives built into the system by IS policies, as IS industries receive stronger incentives still. In those cases, exports often consist of "excess capacity" output of IS industries, and do not necessarily represent industries with long-run comparative advantage.

The reasons that countries which have genuinely biased their regimes toward export promotion have tended to experience more satisfactory growth rates can be summed up as the counterpart of the IS problems: stop-go patterns do not seem to emerge due to foreign exchange bottlenecks; efficient low-cost firms can expand very rapidly well beyond the limits of the domestic market; and domestic monopoly positions do not spring up as firms are forced to compete for their customers abroad and heed quality control and specifications. In addition, despite bias toward EP, the extent of the bias cannot get too great: countries adopting IS with the domestic price of importables twice or more the international price are frequently noted; countries with EP with a bias of more than 25 or 30 percent towards exports are rare.

From this brief glimpse of the factors differentiating growth patterns under EP and IS, $-5 /$ it is evident that there can be significant impacts upon economic growth rates by the choice of strategy adopted. But, in the presence of a fairly convertible exchange rate permitted to move with changes in the rate of inflation, it is not evident that the rate of inflation need be a factor in the choice of trade strategy: the two are or can be independent. 
Inflation and Growth

There is presently in economics a revival of interest in the costs of inflation, and little time need be spent on them here. As inflation accelerates, transactions costs rise and individuals seek stores of value to replace money in that function. These can be costly activities, as potentially productive resources (such as those producing gold and real estate), are diverted to providing a store of value with little increase in society's real product resulting. In addition, to the extent that countries have geared their spending and taxing policies to stable prices, the costs of the distortions introduced by the tax system may be quite large. Finally, in cases where there is credit rationing and borrowers are paying negative real rates of interest, as has occurred in many LDCs, significant resource misallocation can arise on that account.

These costs may be highly significant, and it is not intended to minimize their importance. There is little hard evidence, however, that the rate of inflation itself affects the rate of growth via these channels. Given the structure of production in most developing countries, it is likely that the biggest impact of inflation on growth in LDCs has arisen when the underlying premise of this section has been violated: a major and detrimental impact of inflation has been the erosion of the real exchange rate with significant results for the country's trade and payments position 
and the nature of its trade regime. It is these costs which must be analyzed in order to evaluate the impact of stabilization programs upon economic growth.

Altering the Trade Regime.

If bias toward IS were provided only by tariffs or export subsidies, alteration of the trade regime could be accomplished by altering the tariff or subsidy rates. However, as already stated, IS policies are often carried out through quantitative restrictions, and alteration of the bias of the regime entails shifting from reliance upon QRs to reliance upon prices, and may indeed involve replacing the bias imparted by QRs with a similar bias imparted by tariffs.

One of the difficulties of altering trade regimes is that the extent of bias is frequently not known. Especially when QRs are important, it turns out that a move from QRs to tariffs alters the bias of the regime much more than intended by the authorities: they are simply unaware of the protective equivalent of the quotas. 6 /

Regardless of the way in which bias toward Is is reduced, $\underline{7}$ resource reallocation will follow. Should the profitability of existing industries be reduced (as for example if there is an increase in the value of import licenses issued) without any offsetting stimulus to other industries, a reduction in the level of economic activity is the likely outcome. This is especially the case if expansion of the industries whose relative profitability has increased will require 
investments to expand capacity, while output can contract immediately in IS industries. For, entrepreneurs without experience in exporting activities may be very reluctant to base large-scale investments upon the expectation that they can profitably sell international markets: on one hand, they may be inexperienced in those markets and be unaware of the opportunities facing them; on the other hand, they may be well aware of those opportunities, but fear that the altered bias of the trade regime (with a more favorable real exchange rate) may not last, thereby rendering investment unprofitable.

These considerations pinpoint two aspects of any adjustment process which involves a shift in the bias of the regime: on one hand, there is likely to be something of a disparity between the rate at which existing industry cuts back production and the rate at which potentially new industries increase output; $\underline{8}$ on the other hand, the role of expectations is crucial in determining how significant and long-lived the disparity is. If entrepreneurs are convinced that the change in incentives is permanent, the disparity may not last long. If, on the other hand, there are significant doubts about the ability of the authorities to maintain the new relative price structure, output of industries encouraged by the former bias of the regime may contract while there are few moves made to start increasing output along new lines. It is this latter case in which the growth costs of a shift in the trade regime can be potentially substantial.

It seems evident, therefore, that an attempt to alter the bias of a trade regime should be accompanied by some stimulus to activity 
in the newly-profitable industries, and perhaps also some increase in the general level of aggregate demand to offset whatever decline will come about in the adversely-affected industries. The severity of the downward pressure on the level of economic activity depends upon a number of factors, including the degree to which bias is being altered, the height of the protective barriers being reduced, the degree of uncertainty as to the permanence of the altered incentive structure, and the length of time the incentive structure has been in place. Even in the absence of any inflationary pressures or other objectives, a policy shift with regard to trade strategies is likely, therefore, to entail some short-run costs in terms of the rate of economic growth. If the shift is successful, however, the short-term loss may be earning a relatively high rate of return in the form of improved resource allocation and more rapid growth in future periods. A major question, of course, is how the costs of such a shift may be minimized and, simultaneously, the extent to which policies can be introduced to offset part or all of the shortterm losses. It seems best, however, to consider that question in the context of a total stabilization policy package.

Costs of Reducing the Inflation Rate

Little needs to be said here about the difficulties involved in reducing the rate of inflation in developing countries. There have been a few notable instances of successful, and fairly painless, sharp 
drops in the rate of inflation, but they are the exception rather than the rule. Israel in the mid-1950s, Turkey in 1958-59, and South Korea in the late 1950s and early 1960s are three countries that were able successfully to bring about a reduction in their inflation rates of two-thirds or more. In those instances there was little retardation in the rate of economic growth. $9 /$

A more prevalent pattern appears to be one in which "stabilization" programs are adopted, and some deceleration of inflation occurs. That deceleration, however, is accompanied by recession. In some instances, such as Brazil in the mid-1960s, the costs of stabilization in the form of below-capacity output were borne for several years, until the inflation rate had been significantly reduced. Even more frequently, however, recession and its effects have put such pressure on the political authorities that the stabilization attempt has been abandoned. The Chilean experience of the 1950s and 1960s seems to have been characterized by this sort of stabilization. $10 /$ The cost of reduced inflation was recession, and resumption of economic growth occurred only after the stabilization effort was abandoned; with resumed growth, the rate of inflation (and the bias toward import substitution) once again increased.

For later reference, there is one aspect of attempts to reduce inflation that should be noted. That is that there is one type of deflationary policy which can simultaneously assist in altering the bias of the regime and reducing the inflation rate: increasing the flow of imports. To the extent that financing can be found 
to achieve such an increase, purchasing power is absorbed while the implicit or explicit bias toward import substitution is substantially reduced. This feature is of special significance in considering stabilization policies and ways in which measures can be taken to improve the likelihood of their success and reduce their short-term costs.

Interactions Between Inflation and the Trade Regime

As already mentioned, determinants of the rate of inflation and of the bias of the trade regime are, in principle, largely separate. One of the policy measures that can be taken to reduce the distortion and growth costs of inflation is a sliding peg exchange rate regime. To be sure, the optimal real exchange rate which is itself a function of the desired bias in trade strategy and other variables will not under all circumstances remain the same. As Carlos Diaz noted for Colombia, with the fluctuations that country has faced in the price of coffee, there is probably no exchange rate that was not an equilibrium rate at one time or another. $11 /$ Nonetheless, while alterations in the real exchange rate may prove desirable in response to altered prices for the country's exports on the world market or for other reasons (including a desire to shift the bias of the trade regime) there is little likelihood that rates of inflation will reflect only those changes. 
Thus, if a country with a fixed exchange rate found that its price level was beginning to increase more rapidly than that of its trading partners, the best policy in the absence of willingness to allow freely-fluctuating exchange rates would most likely be some form of indexation (sliding peg) of the exchange rate. Various formulae are possible: the exchange rate can be set relative to a major trading partner in conformity with the differential between the country's and the trading partner's inflation rate; a weighted average of the rates of inflation adjusted for exchange rate changes of several major trading partners can be deducted from the country's own rate of inflation. In different circumstances, the number of countries it is desirable to include in the calculus can differ but in all cases adjustment must be made at fairly short time intervals. Under any of these formulae, changes in the rate of inflation will not have a significant impact upon the nature of the trade regime. Such an indexation works best when inflation rates are fairly stable or declining; there is some tendency toward balance of payments deficit when inflation generate by excess demand is accelerating over into the foreign exchange market. Nonetheless, contrasted with the maintenance of a fixed nominal rate of exchange under inflation, a sliding peg policy is vastly to be preferred.

The difficulty, and one which results in the important interaction between trade regimes and inflation, arises in countries 
that fail to adopt such a strategy. In those cases, inflation tends to increase the purchasing power of domestic currency when spent abroad relative to its value when spent at home. As a consequence, domestic nationals tend to increase their purchases abroad and reduce their sales abroad. In the absence of capital controls, they also try to exchange domestic assets denominated in domestic currency units for foreign assets denominated in foreign currency units.

In those instances, countries have three choices: to incur open balance-of-payments deficits; to alter the price paid and received for foreign exchange defacto or de jure; or to impose quantitative restrictions upon international transactions. In practice, the response is usualiy to adopt some price measures, such as surcharges upon imports and subsidies for minor exports, to impose some QRs, and to permit a deficit in the balance of payments to emerge, financed by running down foreign exchange reserves or borrowing from abroad. Indeed, one characteristic of many inflation-prone countries attempting to maintain a fixed exchange rate is the proliferation of fairly detailed, ad hoc, measures designed to curb excess demand for foreign exchange side-by-side with the continued need to borrow from abroad to finance deficits that emerge despite measures taken. This welter of detailed and fairly specific measures itself has economic 
costs, and can be one motive for a stabilization operation -"tidying up" the regime.

For purposes of analysis, however, it is convenient to set aside the use of price measures and mixed responses. If sufficient price measures were undertaken on an across-the-board basis to remedy the underlying tendency toward excess demand for foreign exchange, such measures would amount to a sliding peg exchangerate policy. It is the absence of sufficient pricing measures that forces countries experiencing inflation at fixed exchange rates to adopt alternative measures.

The alternatives consist of incurring open balance-of-payments deficits, financing them by running down reserves or borrowing from abroad, or of imposing quantitative restrictions. Each of these measures has costs and affects the nature of any subsequent stabilization program. For purposes of analysis, it: is useful to analyze each type of response separately, al though as already indicated the two are often found in combination.

Table 1 is again useful as a frame of reference. It will be recalled that the sliding peg (if pegged at the appropriate level) or flexible exchange rate case was one where each market cleared and participants were free to carry out desired transactions at the prevailing prices. Incurring an open payments deficit is equivalent to permitting an excess supply of money in the home market to 
spill over into realized excess demand for goods and services from abroad (which is reflected in the payments deficit). By contrast, exchange control is a case in which individuals are not permitted to carry out their desired transactions: the domestic price of importables exceeds the foreign price-cum-tariff, and the money market consequently clears. The precise mix of these two policies in use is a critical factor in determining the effects of policies that are undertaken in a stabilization program.

Payments Deficit

The key characteristics of a response to excess demand by permitting a payments deficit are two: on one hand, there is an excess supply of money, and on the other hand, the relative price of home goods is "too high," as aggregate consumption is above sustainable levels, consumption of home goods increases, and the failure of the price of tradables to use induces production to shift toward home goods.

The excess supply of money is in part a reflection of the fact that the fixed exchange rate acts as a suppressant to the inflation that would otherwise result from aggregate demand pressures. In the case of a sliding peg exchange rate policy, the entire inflationary stimulus is passed through both the home goods and the traded goods sector: both prices increase nominally and there is no relative price change. In the case of a fixed 
exchange rate, home goods prices rise (although not by as much as they would under a sliding peg because consumers are permitted to substitute traded goods for home goods in their consumption bundle while producers shift production away from traded and toward home goods), but traded goods prices are stable. The payments deficit can be thought of as a reflection of that part of the inflationary pressure which did not get reflected in price increases.

A straightforward way of viewing the problem of a country experiencing inflation and a payments deficit at a fixed exchange rate is to recognize that the inflation rate is held below that which would otherwise be realized as long as the exchange rate can be maintained, both because the price of tradable goods does not rise and because the increase in the price of home goods is less than it would otherwise be. Under those circumstances, devaluation is inflationary: it permits the inflationary impulse to be passed on to the domestic market. Devaluation would therefore accomplish little if a country could continue indefinitely to finance its payments deficits. 12 /

The fact is, however, that countries cannot indefinitely run down reserves or borrow from abroad for purposes of financing their deficits. Just as an individual consumer can live well beyond his means by running up credit card charges, borrowing from his bank, 
and depreciating his consumer durables, so too can a country live beyond its means. In both cases, the situation is not sustainable.

It is for this reason that analysis of the costs, in terms of growth prospects, of measures taken to el iminate an unsustainable deficit is extremely difficult. In a sense, the economy incurring a deficit and then reducing its expenditures relative to its income is on a non-optimal path: its early level of expenditures and outlay is too high, at the cost of a later reduction in that level. For purposes of analysis, the best that can be done is to pose the question in the following way: given an economy which has incurred an unsustainable deficit, what is the lowest-cost way of altering its experiditure-income relationship to reattain a sustainable future expansion path? Consideration of this question is deferred until the third section of this paper. At this point, it should merely be noted that the line of analysis sketched out here applies to any country's attempt to reduce the size of its payments deficit, actual or in prospect. In many instances, stabilization programs have objectives pertaining both to reducing the size of the prospective deficit and to liberalizing the trade regime. Before analysis of those programs can be carried out, therefore, it is necessary to examine the differences between the goals and the problems implicit in the two alternatives. 
Liberalizing the Trade Regime

As already mentioned, inflation at a fixed exchange rate cannot long be sustained without incurring a payments deficit. That is unsustainable, and the alternative is alteration of the exchange rate or the imposition of quantitative restrictions once access to further foreign credits becomes limited, as it eventually must. They key characteristic of using QRs to keep foreign exchange payments in line with receipts, as shown in Table 1, is that the money market is permitted to clear while the domestic price of importables rises above the imported price (inclusive of landing costs, tariffs and surcharges). Thus, whereas an open payments deficit is characterized by the inappropriate relative price of tradable to nontradable goods (for any chosen tariff structure), the quantitative restrictions equilibrium is characterized by a greater bias of the trade and payments regime toward import-competing activities domestically than would be chosen simply on the basis of the industrialization strategy. Whether home goods relative prices are likely to be higher or lower than in the flexible-exchange rate alternative is not clear-cut: depending on the nature of the structure of production and the degree of substitution between exportables, importables and home goods in both consumption and production, that relationship can go either way. 
The difference between the price that prevails for an import in the home market if individuals were allowed to import all they wished at the prevailing price and the price that would prevail in the presence of quantitative restrictions upon imports is referred to as the premium on an import license. The very fact that there are premiums on import licenses is usually sufficient evidence to indicate that quantitative restrictions are binding. Under those circumstances, the bias of the trade and payments regime toward IS is almost always greater than intended, and resource allocation costs can mount well above those associated with the tariffgenerated protection. $13 /$

Thus, although either an open payments deficit or the tightening of quantitative restrictions can result from inflationary pressure at a fixed exchange rate, the symptoms and resource allocation effects of the two alternative responses are quite different: the realized rate of inflation for a given monetary stimulus will be greater under a $Q R$ response than under a deficit response; the degree of bias of the regime will be greater under the $Q R$ response than under the deficit response; and the home-goods sector will likely expand more under the deficit response than under the $Q R$ response. $\underline{14}$ When stabilization programs are adopted, therefore, it depends crucially what mix of the two policies has been chosen, and of course, how severely restrictive $15 /$ the QRs have become or how sizable the deficits are. 
When the response to potential deficits has been the imposition of quantitative restrictions, increasing the price of foreign exchange will operate rather differentiy than it will in the case of open deficit. Suppose, for example, that an open deficit has been incurred. Raising the price of foreign exchange while holding tariffs constant will, in the absence of quantitative restrictions, raise the price of tradable goods relative to the price of nontradables. For a small country with no monopoly power in trade, the relative price of exportables and import-competing goods will remain unaltered: the bias of the regime is unaffected, although production of both import-competing and exportable goods becomes more profitable relative to the profitability of producing home goods. $16 /$ If, instead, QRs are in effect prior to the increase in the price of foreign exchange, part of the increase in price will go to absorbing the premiums on import licenses (thereby perhaps reducing the variance in effective exchange rates across commodity categories). If, as is usually the case, export subsidies are much smaller than premiums on import licenses, a far higher fraction of the increased price of foreign exchange will be reflected in the domestic price of exportables than it will be in the domestic price of importcompeting goods. At the limit, in cases where the size of the devaluation is less than the size of the preexisting premium on import licenses, there is no reason to expect the domestic price of importables to rise following a devaluation. 17/ 
Several points should be noted. First, as a consequence of premium absorption, the increase in the price level following a devaluation in the context of preexisting QRs should be considerably smaller than the recorded price increase following a deficitreducing devaluation. In a sense, this is the counterpart to the statement that a given inflationary stimulus will result in a larger rate of inflation under QRS than it will under an open deficit given a fixed exchange rate: the devaluation has more work to do correcting the relative prices of exportables and importcompeting goods and less work to do in adjusting the price lever. Second, in the absence of other policy moves, any devaluation is still likely to result in a reduction of the restrictiveness of whatever quantitative restrictions are in effect. That is, for given quantitative amounts of permitted imports, devaluation automatically liberalizes a given trade regime, unless other measures are taken to offset the increase in the price of foreign exchange. 18/ Third, because devaluation absorbs premiums upon imports, it automatically alters the bias of the regime and thereby induces the resource reallocation mechanisms discussed in the first section of this paper.

Finally, there is the question of the macroeconomic impact of a pure "liberalizing" devaluation. Unlike the open deficit case, where expenditures clearly have to be cut relative to income, the "liberalizing" devaluation has no such imperative, except insofar 
as it was underlying the erosion of the real exchange rate which led to the necessity to impose QRs in the first place. In principle, therefore, if a $Q R$ regime were the result of past inflationary pressures which had subsided, leaving the exchange rate overvalued by a stationary amount, no defiationary stimulus or reduction in the level of aggregate demand would be called for. Indeed, in the pure $Q R$ case, it can even be argued that the absorption of the premium by the exchange rate increse, combined with the benefits from resource allocation resulting from the change in the bias of the regime, might well result in a mild deflationary pressure on the economy. $19 /$ Quantitatively, however, it is not evident that this deflationary pressure is likely to be significant.

Stabilization Programs and Long-Term Development

As the foregoing has indicated, there is no one action that can be described as a "stabilization program." The policies undertaken, and their effects, vary depending on the underlying situation and the goals of the policy makers.

It has already been indicated that the task of reducing the rate of inflation is an exceptionally difficult one: almost inevitably there is a short-term reduction in the rate of growth of output, and in many cases, recession. In these circumstances, deflationary policies are sometimes reversed so that few, if any, benefits are realized. Likewise, the resource reallocation that must accompany a successful effort to liberalize the trade regime 
and alter its bias away from import substitution cannot be achieved without inevitable adjustments of resources within the economy.

For these reasons, there are bound to be short-run adjustment costs of any stabilization program, whatever the nature of the policy package and regardless of the degree to which it is successful. There are, of course, ways of reducing those costs, but it is doubtful whether stabilization can be accomplished in the presence of unwillingness or political inability to withstand some short-term disallocations. The first and most important conclusion that can be drawn, therefore, is that it is senseless to incur the costs of adjustment, only to reverse policies before they have had any chance to affect resource allocation and growth. Yet, the evidence is that a significant number of stabilization programs have foundered precisely because the authorities have been unwilling or unable politically to survive political pressure during the adjustment period. $\underline{20 /}$

A second conclusion, which follows readily from the first, is that the reallocations will take longer and be more difficult the greater are expectations that the realigned structure of relative prices and incentives will not continue. If it is expected that the devaluation and liberalization will be short-lived, businessmen and consumers are likely to stockpile foreign goods in anticipation of possible future reimposition of QRs. In doing so, they increase the current account deficit and therefore the foreign exchange 
outflow required to sustain the liberalization program through the adjustment period. In the context of a situation in which foreign exchange has earlier been in excess demand because of the trade regime, increases in imports and current account deficits may stimulate further speculation against the exchange rate, in turn tending to force the reimposition of controls. In addition, expectations of reversal discourage resource reallocation thus blunting the increase in exports that might otherwise be experienced.

Thus, one objective of policy should be to insure that a stabilization program, once undertaken, can be sustained long enough to provide an opportunity for its results to be felt. This in turn suggests that a desirable feature of any stabilization program is that it should be designed in such a way as to suggest to economic agents that it will succeed: expectations are likely to be self-fulfilling. This conclusion has numerous implications for policy, especially for the evaluation of the optimal lending strategy for donors in connection with stabilization programs.

For the longer term, the effects of stabilization on the rate of growth are a function of the objectives of the program (and especially the extent to which the bias of the regime is shifted away from undue emphasis upon import substitution) and the degree to which they are accomplished. If, as was the theme of Section II, stabilization policies are undertaken in the first place because existing policies are unsustainable, it is difficult to talk about 
the growth effects of alternative packages except in the context of the alternative stabilization packages: continuation of the status quo ante is infeasible. It is for this reason that one can regard the biggest growth cost of stabilization programs as lying in their failure: when a program does not succeed, it is generally inevitable that another program, with the same sort of short-run costs, will have to be adopted in the future. To the extent that every failure of such a program intensifies expectations of failure of the next one, an unsuccessful stabilization program may itself have growth costs, not only in the current slowdown in economic activity which by definition has no payoff, but also in the heightened cost of achieving the same objectives at any future date, when memories of past failures make expectations more skeptical about the likelihood of success. The Colombian experience of the late 1950s and early 1960s is perhaps an excellent example: after devaluation attempts which were unsuccessfur in 1956, 1959, 1961 and 1966, the authorities successfully began altering the bias of the related policies in 1967. Carlos Diaz-Alejandro concluded that one of the major impacts on Colombian growth was that the consequent growth of foreign exchange earnings from increasing exports meant that the stop-go cycle of fiscal and monetary policy surrounding stabilization efforts finally stopped, which in turn permitted a more rapid rate of growth of the entire economy. 21/ 
It therefore seems appropriate to attempt to categorize stabilization programs in terms first, of the primary objectives of the program, then of the preexisting situation, and finally, the policy measures taken.

Objectives

Despite the fact that almost all stabilization programs by definition have some bearing on both inflation and balance of payments objectives, the relative importance of the two objectives can differ. In some instances, stabilization programs are geared primarily toward reducing excess aggregate demand, with balance of payments targets secondary. $22 /$ In other instances, the infeasibility of continuing to incur indebtedness or of further tightening QRs makes the primary target an alteration in the trade regime. $23 /$

One fundamental lesson that seems to emerge from examination of the cases in which devaluation did not succeed in relaxing the foeign exchange constraint is that it does not make sense to tie the success of the measures aimed at the foreign trade sector to success in reducing the rate of inflation. It appears to be the case that it is significantly easier to alter the real exchange rate and to increase the rate of growth earnings than it is to reduce the rate of inflation permanently. This is perhaps the strongest argument that can be made on behalf of a sliding peg policy: it permits the success of the trade component of a stabilization program independently of whether the rate of inflation drops or not. In light 
of the already-stated result that one of the significant costs of inflation 1 ies in the distortions introduced by a fixed exchange rate, it is difficult to understand countries which attempt to alter their trade and payments regimes and inflation rates by adopting a new, fixed exchange rate: if the rate of inflation does drop, a sliding peg will not significantly alter the exchange rate, and both objectives of the program will be met; if, however, inflation is not successfully controlled, both objectives of the package are bound to fail if a new, fixed exchange rate is set.

Because controlling inflation is inherently the more difficult objective in most circumstances, and because those primarily concerned with bringing the rate of inflation down are likely to object to a sliding peg as being more inflationary than a new fixed exchange rate, it seems to be the case that stabilization programs motivated more by a desire to alter the trade and payments regime have a somewhat greater probability of partial or total success than do programs aimed primarily at the rate of inflation.

To be sure, neither sort of change -- alteration of the trade regime or changing the inflationary nature of the economy -- is likely to be easy, for reasons already mentioned. Nonetheless, there are degrees and degrees of difficulty, and controlling inflation does seem much the more difficult of the two objectives. 
Preexisting Conditions

A number of circumstances in the preexisting situation also have a bearing on the probable outcome of the stabilization package. Ainong the most important are "chance" elements, the set of macroeconomic influences currently operating on the economy, the extent to which the trade regime has been characterized by QRs or by open deficit, and the magnitude of foreign short-term indebtedness.

Turning to the chance factors first, two especially should be noted. On one hand, favorable harvests can significantly increase the probability that a stabilization program will prove successful. This is because good harvests tend to keep the domestic prices of foodstuffs relatively low, thereby exerting downward pressure on the overall price index, and also because bumper crops tend to increase quantities available for export, thus increasing foreign exchange earning. The latter results either in increased foreign exchange reserves, and thus conviction that the altered incentives will continue or in an enhanced flow of imports, which in turn permits a relatively greater degree of bias toward exportables than would otherwise be possible. The other event that can positively affect the outcome of a stabilization program is favorable movements in the terms of trade. Such an outcome has the same sort of impact as the increased export earnings that can be attained with a good harvest, although the impact is less favorable on the inflation rate, and appropriate policies must be followed 
to prevent increased prices of key exports from resulting in large increases in domestic money supply and purchasing power. There have been instances of stabilization programs which, on the historical record, appear to have had a good chance of success which have foundered on unfavorable movements in the terms of trade. The Brazilian devaluation-and-stabilization effort of 1957 appears to have been one such case: the volume of exports increased almost fifty percent over the ensuing twenty-four months, but export earnings rose hardly at all. 24/

Macro influences are several-fold. First, there is the nature of the monetary and fiscal policies in effect in the six to twelve months prior to the stabilization effort. When those have been highly expansionary, the difficulties entailed in successfully carrying out stabilization are likely to be much greater than when monetary and fiscal stimuli have been moderate. Indeed, it can even be contended that, in the presence of highly expansionary monetary and fiscal policy over the preceding year, a country would be better off to postpone (if possible) altering the trade regime (especially if a sliding peg is not a realistic alternative) until monetary and fiscal magnitudes have been brought under control. Second, there is the extent to which price controls have prevented excess demand pressures from being realized. When those factors have been of importance, it is usually necessary to remove those price ceilings at the time the stabilization package is inaugurated. As prices must rise from their formerly-controlled levels, any cost-push 
responses within the economy will be triggered by those increases as well as the increase in the price of tradable goods thereby making the task of reducing the rate of inflation more difficult. Nonetheless, when price controls have been operative pre-stabilization, their removal can be an essential part of the stabilization package. When those controls are over public-sector products, they may have been a significant factor in contributing to the public-sector deficit and thus increases in the money supply. Such was the case in Turkey in the late 1950s, when public sector enterprises were required to maintain prices well below costs of production. Deficits, financed by Central Bank credits, were a chief source of inflationary pressure. Raising the prices of public sector enterprise outputs resulted in a once-and-for-all increase in the price level by 20 percent, but simultaneously eliminated the further extension of Central Bank credits. The consequence was that, after several years of inflation recorded at 25 percent annually or more (despite the price controls wich had suppressed it), prices actually fell in the two years following the increase in public sector enterprise prices.

Finally, there is the preexisting situation with respect to the trade regime and the balance of payments. For reasons outlined above, it makes a significant difference which stabilization program is aimed primarily at reducing or correcting an existing or prospective open deficit, or whether instead it is intended to liberalize the trade and payments regime and to reduce or eliminate quantitative 
restrictions as a means for keeping foreign exchange receipts in line with payments. In addition, the degree to which debt-servicing difficulties are being experienced and imports have been curtailed prior to the stabilization program is also significant in influencing the nature of the package and the probable effect of any given set of policy changes.

In general, if imports have been sharply curtailed in the months or years prior to stabilization, the prospects are that an increased import flow can significantly affect real output, even in the shortrun. 25/ If, on the other hand, imports are running at high levels, a stabilization program which curtails imports will likely be necessary. Import curtailment is in itself inflationary, and may also impair domestic production levels if imports of intermediate and capital goods are used more or less in fixed proportions in domestic production.

The extent to which debt-servicing commitments exist prior to the stabilization package, and the ways in which rescheduling is needed and handled within it, are also important. The existence of debtservicing obligations which cannot be met reflects, to be sure, the fact that the country has in the past lived beyond its means. The fact that stabilization packages are often postponed until debt-servicing obligations force governments into negotiations with consortia of creditors is also a reflection of governments' unwillingness to take the short-term costs of stabilization. 
The difficulties that can arise as a result of bargaining over debt-rescheduling can be important, both politically and psychologically, in affecting a stabilization program. Pressing debt-service obligations can induce governments to accept conditions from consortia of creditors as a prerequisite for debt rescheduling. In some instances, this may enable politicians to take measures they would not otherwise politically be able to take. In other cases, politicians may not accept the necessity for those measures, in which case they may carry them out only belatedly and begrudgingly. In the latter case, prospects for the longer-term success of the stabilization program are small: the objectives are really those of the creditors and not those of the debtor country. $\frac{26 /}{}$ When debt-service rescheduling becomes critical, however, donors as well as debtors are caught: failure to impose some conditions upon borrowers at that time will force them to lend more later in the absence of policy measures and, if a government is unresponsive, creditors will eventually use the country's prospective default as a means of correcting the situation.

\section{Policies}

As already stated, there is no single set of policies that constitutes a "stabilization program." Programs can range all the way from fairly minor adjustments of exchange rates and macroeconomic policies with only limited objectives to attempts to correct high rates of inflation and severely restrictive $Q R s$. 
In terms of their effects on economic growth, the successful stabilization programs are those that succeed in one or more of the following: 1) significantly altering the bias of the trade and payments regime away from import substitution; 2) moving the economy away from reliance upon quantitative restrictions and toward pricing measures; and/or 3) permitting a movement away from stop-go cycles of growth resulting from a foreign exchange "bott 1 eneck."

Here, we discuss the policies that can constitute part of such a program. First, there are the already-mentioned monetary and fiscal policies. These often entail a reduction in the extension of credit within the economy, ceilings upon levels of government expenditures, and measures to increase tax collections. In addition, they may involve the removal of price ceilings and other measures which may have contributed to government deficits and increases in the money supply. Reichmann and Stillson? have tabulated the "financial programs" implemented as part of stabilization programs for the 79 instances in which higher credit tranches were utilized during the 1963-72 period. These cases involve both developed and developing countries, but are nonetheless instructive. Their classification of cases is reproduced in Table 2 below. In their terms, "no deceleration" refers to cases where credit expansion was to be permitted to continue at its present rate. As can be seen, the single largest group of countries resorting to higher credit 
Table 2. Financial Programs as a Component of Stabilization Programs, 79 Countries, 1963-72 (number of programs)

\begin{tabular}{|c|c|c|}
\hline \multirow[b]{2}{*}{ Main Purposes } & \multicolumn{2}{|c|}{ Credit Policy to be Implemented } \\
\hline & Deceleration & No Deceleration \\
\hline $\begin{array}{l}\text { Correction of overly expansionary } \\
\text { dernand policies }\end{array}$ & 26 & $\cdots$ \\
\hline $\begin{array}{l}\text { Modification of exchange system and } \\
\text { correction of overly expansionary } \\
\text { demand policies }\end{array}$ & d & $\cdots$ \\
\hline Modification of exchange system & 7 & 13 \\
\hline $\begin{array}{l}\text { Other } \\
\text { (of which:) }\end{array}$ & 3 & 26 \\
\hline (Anti-recessionary program) & $(-)$ & (5) \\
\hline $\begin{array}{l}\text { (Cope with temporary shortfall } \\
\text { in exports) }\end{array}$ & $(-)$ & (11) \\
\hline Total & 40 & 39 \\
\hline
\end{tabular}

Source: Reichmann and Stillson, op. cit., p. 297. 
tranches in IMF Stand-bys were categorized as having "overly expansionary demand policies" and their rate of credit expansion was to be reduced as part of their stabilization programs. There were, however, 13 cases in which the objective was to modify the exchange system and deceleration of credit expansion was not called for. In some of these cases, the authorities had begun instituting restrictive credit policies prior to the stand-by agreement, so no further deceleration was warranted.

In some developing countries, notably Korea, a significant component of the altered growth structure of the economy has originated from interest-rate reforms undertaken in conjunction with the reform of the exchange system. In Korea, inflation had made the real interest rate significantly negative, and interest rate reforms raised the nominal rate of interest from 5-8 percent to 25-30 percent (with an inflation rate of about 20 percent). Although other factors also contributed, the Korean savings rate rose dramatically after the interest rate reforms and this factor was one contributor to the large jump in the growth rate achieved subsequently.

With the exception of the interest-rate reforms, however, most macroeconomic policies adopted as part of a stabilization program do not impact directly upon the three variables listed above as being significant for growth prospects. Rather, they constitute part of the background setting for alterations in the 
trade and payments regime and their chief significance $l i e s$ in determining whether the chosen nominal fixed exchange rate can remain realistic in real terms for a significant period of time.

The trade-and-exchange-rate components of stabilization programs are even more varied than their macro-monetary counterparts. The sorts of policies adopted can be loosely categorized under four main headings: exchange rate changes; liberalizing the import regime; altering the bias of the regime; and debt rescheduling.

Exchange rate changes have been discussed. As indicated, a part of the change in the nominal exchange rate is often absorbed by the removal of export subsidies, import surcharges, and other partial measures taken prior to devaluation, and it is "net," and not gross, devaluation that affects individuals' decisions. To be sure, there is probably some improvement in incentives resulting even from this tidying up, as the replacement of surcharges and subsidies with the exchange rate usually results in greater uniformity of incentives and effective exchange rates across transaction categories than exists prior to the change.

The preceding analysis also demonstrated that the impact of a net devaluation can be quite different depending on whether the preexisting situation was one of a $Q R$-achieved balance in payments or of an open deficit. In the former case, alteration of the exchange rate automatically results in some liberalization of the regime and, insofar as export subsidies were not as large as import 
premiums, a reduction in the bias toward import substitution. In an open-deficit prior situation, devaluation is more likely to result in an equiproportionate rise in the domestic prices of tradables, and the chief relative-price effect is the relative price of tradables in terms of home goods.

Liberalizing the import regime can come about not only through exchange rate changes when import premiums on 1 icenses are absorbed, but also through alterations in the control mechanism itself. $28 /$ Many stabilization programs have been accompanied by a revision of the licensing system, often with the introduction of a group of "priority" or "liberalized" imports, for which licensing procedures are streamlined if not abandoned. A variety of techniques for achieving liberalization have been used. In some countries, a shift from a "positive" list (only items listed are permitted to be imported) to a "negative" list (all items not listed may be freely imported) has resulted in significant liberalization. In other countries, removal of "guarantee deposit" requirements, under which would-be importers deposit amounts equal to some multiple of their import license with the central bank pending receipt of the import, can represent a sizable liberalization. In Chile, for example, the authorities have imposed guarantee deposit requirements of 10,000 percent in periods of severe foreign exchange shortfalls prior to devaluation, and removal of those requirements has defacto permitted a resumption of imports. $\frac{29 /}{}$ Even moving from monthly to quarterly or semi-annual import programs can result in liberalization 
of the regime, as can such measures as permitting the resale of import licenses and removing restrictions on currency areas in which licenses are utilized.

Alteration of the bias of the regime comes about through the exchange rate change itself (insofar as it is net), with absorption of premiums on import licenses as the regime is liberalized, and also through policies designed directiy to encourage exports. Especially important can be assurances to exporters that the newlyachieved real exchange rate for exports, and other incentives for exports, will continue. In some instances, this has been accomplished in part by the removal of domestic taxes on export production. In Brazil, for example, removal of state and federal taxes on exports made selling domestically and selling abroad at two-thirds the price approximately equally profitable. $\underline{30 /}$

Finally, there is the matter of debt-rescheduling and borrowing to finance an increased flow of imports. Debt rescheduling is often a prerequisite for any degree of liberalization of the regime and continued economic growth because, by the time of the stabilization program, the country's existing debt-service and repayment obligations are so large that the alternatives are default or an import bill so small that domestic economic activity will have to be severely curtailed. In addition to rescheduling, creditors, and especially aid donors, have often extended additional credits to the country at the time of stabilization to permit an immediate increase in the import 
flow before export earnings and other foreign exchange receipts respond to the altered incentives provided by devaluation and its accompanying measures.

Trade-0ffs in Stabilization Programs

Enough has been said already to pinpoint the chief areas of trade-off in deciding upon the nature of a stabilization program. Essentially, there are three crucial, and interrelated, areas where significant trade-offs exist. The first is between the short-run and the long-run. The second is between gradual but continuing small changes and large changes. The third is between more foreign borrowing and greater deflationary pressure as part of the stabilization program.

Short-Run versus Long-Run

If one were to pinpoint the most significant trade-off in stabilization programs, it is clearly the trade-off between short-term cost and longer-term benefits. For reasons already spelled out, stabilization programs are almost inevitably going to entail some short-run costs as a necessary price for achieving longer-run benefits. Especially when the changes that must be brought about involve both the rate of inflation and the bias of the trade regime, short-run adjustment is inevitable. Two or three additional percentage points per year of growth of GNP can be achieved by countries successfully altering their trade bias and payments regime. For those countries, the short-term costs, which 
are probably on the order of one or two percentage points of GNP for a year or eighteen months, are greatly exceeded by the discounted value of higher GNP at later dates. $\underline{3 / /}$

The difficulty, of course, is that politicians must inevitably face the short term before reaching the long term. The myopic nature of the political process is well understood. Thus, one can well imagine situations in which alteration of the bias of the regime might well yield a social rate of return in excess of 15 percent on the short term costs and yet be rejected by the political process.

The fact that the politics of stabilization are difficult makes matters worse than they would otherwise be. Not only are politicians likely to use higher rates of discount than may be warranted, but the fact that they may be unwilling to withstand the pressures that arise during the transition period raises the possible costs of embarking on a stabilization program. For, while the benefits to be achieved by a successful stabilization program involving moving away from import substitution are not likely to be affected, the fact that politicians may decide to abort a stabilization program before its benefits begin to be realized raises potential costs. A donor, considering whether to push for a stabilization program and shift of trade orientation, must weigh the possibility that the program may be aborted (which will raise costs for the next attempt) as well as the costs of a successful program against the potential benefits. In large part, such a judgment is of necessity political, but that makes the calculus no less necessary. 
Gradual ism versus Shock

The fact that there are likely to be short-run costs associated with any change makes the case for some degree of gradualism: it may diminish the costs of adjustment. On the other hand, the fact that there are likely to be built-in resistances to change (especially among successful import-substitution establishments) and that entrepreneurs must perceive changes in incentives makes a powerful case for a fairly rapid shift in relative prices and in the trade and payments regime.

Here again, the trade-off is much like that between the short run and the long run. There is no doubt that a gradual shift in signals is the more desirable policy if such gradualism does not affect the chances of success of the policy package. If, however, gradualism provides more of an opportunity for failure, as it almost surely does, than a once-and-for-all reversal of signals, then the case for a sharp, once-and-for-all shift in policies is stronger.

As with the short-term long-term trade-off, there are differences between countries in the likelihood that gradual alteration of the regime can be sustained. However, there is undoubtedly some critical minimum initial shift that is essential in order for businessmen and others to perceive that the regime is really altered, and it probably a mistake to accept too gradual an approach. Indeed, there is not a great deal of evidence available as to the different costs of larger once-and-for-all changes and smaller ones spread out over a longer period of time. Nonetheless, 
in view of the political difficulties that are likely to arise if there is a long time period during which adjustment is taking place with few visible signs of success, there is a presumption in favor of a once-and-for-all sharp adjustment.

Foreign Borrowing versus Recession

To achieve a given degree of liberalization of imports (and consequent alteration of bias of the regime), either the level of imports must be increased or income must be reduced in such a way that the demand for imports shifts downward. Thus, liberalization can be achieved either by increasing the size of the flow of imports or by domestic recession. If, as is usually the case, 32 an increased flow of imports can be financed during the initial stabilization period only by foreign credits, an immediate question arises: under what conditions is a country justified in borrowing from abroad in the present (to finance increased domestic consumption) rather than accept a reduction in the level of economic activity?

Again, an answer to the question is partly related to the probability of success of the stabilization program: if the country will, in any event, revert to exchange controls and a strong bias toward import substitution within a short period, it seems to make little sense to borrow currently and to mortgage the future for that purpose. On the other hand, to start out with the view that the program is likely to fail is not acceptable, either.

Assuming that a program is started, therefore, it seems worthwhile to borrow from abroad in order to sustain the increased flow of imports. 
This can be seen in several ways. Suppose a country has a marginal propensity to import (with respect to income) of $m$. Then, for every dollar borrowed from abroad, domestic income can be greater than it otherwise could (for the same degree of liberalization) by $1 / \mathrm{m}$. Unless the marginal propensity to import is extremely high, this would suggest that borrowing from abroad may have a very high social marginal productivity, in terms of the additional level of domestic income it will permit.

Another way of viewing the importance of foreign credits during the stabilization period is to recall that increased flows of imports simultaneously liberalize the regime faster than would otherwise be possible (except with recession) and are deflationary in that they absorio excess aggregate demand. Contrasted with the alternatives of cutting back on the ievel of economic activity or of less liberalization, financing larger import flows appears to be superior, as long as the stabilization program appears to have a good chance of success.

\section{Implications for Donor Countries}

The implications for aid-givers are several. First and most important, aid to support a sustained flow of imports at the time of a stabilization program may, if all goes well, have a very high marginal product if an objective of the stabilization program is to alter the bias of the trade and payments regime. Such aid can be used not only to finance an enlarged flow of imports, but also to reassure potential speculators that the new policies are permanent. Aid that simply increases reserves can be extremely productive. 
Secondly, despite the fact that a country should devalue, considerations pertaining to the domestic political situation are not irrelevant to the decision to undertake a stabilization package, especially its timing. Particularly since the failure of a given stabilization policy makes the next attempt more difficult, there is something to be said for waiting, if at all possible, for domestic political sentiment to support the package. While increasing demands for new loans may force aid donors' and creditors' hands, in cases where it is feasible, postponement of pressure to stabilize may be warranted. In this connection, it should also be remembered that other fortuitous circumstances may affect the outcome of the stabilization effort: especially if signs are for a below-average crop, or for deteriorating terms of trade, postponement of pressures on the debtor country may be wise.

Finally, it should be remembered that a successful stabilization program will have its significant growth impact through the resource reallocation and restructuring of the economy that can result. Those achievements, in turn, can occur only insofar as countries are able successfully to compete in world markets. On one hand, that requires that the countries altering their regimes provide appropriate incentives and support for their enterprises attempting to export. On the other hand, it also requires that donors be willing to permit entry of exports from LDCs into their markets. In terms of the prospects for increased growth through alteration of the bias of the trade regime, the most significant determinant in the long-run 
will be the growth of world markets. For developed countries, the creditors, as a group, maintaining free access to their markets for the products of LDCs may be the single most important policy they can undertake to insure the success of stabilization programs with positive effects on the rate of economic growth. 


\section{Footnotes}

1. For economy of language, I am throughout assuming that the rest of the world is stationary, and there is no inflation or other change abroad. An alternative would be to phrase every statement in terms of maintaining a constant difference in the rates of price increase between the country under consideration and the rest of the world. In the context of economic growth, of course, real exchange rates may have to alter even in the absence of changes in the inflation rate.

2. In principle, there is also a bond market in the system. But in keeping with conventional macroeconomics, I follow the timehonored tradition of assuming that if the money market clears or if all three other markets taken together clear, then the bond market must clear. In practice, among countries with convertible currencies, it can and has been argued that the excess supply of money is more likely reflected in an excess demand for bonds than it is in the goods market. For present purposes, however, that set of questions is well away from our central concern.

3. At first sight, it seems paradoxical that a higher relative price of home goods is associated with greater production. The paradox is resolved if one considers the move from a "full equilibrium" under flexible exchange rates to a new "equilibrium" with the exchange rate held constant but with aggregate demand increased: an upward shift in the demand of home goods means 
the price of home goods must rise and production of home goods increases. Production of traded goods falls while consumption rises, thereby generating a payments deficit in the new "equilibrium." Increased demand for home goods, in turn, usually arises because of excessive money creation or fiscal policy.

4. This is not to state that the real exchange rate should remain unaltered under all circumstances: the proposition is that the underlying determinants of the real exchange rate that will clear the market for traded goods are probably independent of the determinants of the rate of inflation and changes in it.

5. For a fuller discussion of these issues, see my Foreign Trade Regimes and Economic Development: Liberalization Attempts and Conseguences, (Ballinger Press for the National Bureau of Economic Research, 1978), especially Chapters 11 and 12.

6. There are at least two historical instances which are well-documented and where the authorities were apparently surprised by the preexisting level of protection prevailing. See Michael Michaely, Foreign Trade Regimes and Economic Development: Israel and Robert Baldwin, Foreign Trade Regimes and Economic Development: Philippines, both (Columbia University Press for the National Bureau of Economic Research, 1975). 
7. The analysis is similar, although not entirely symmetric, for increasing bias toward IS. The reason for the difference is that entrepreneurs can be expected to be more familiar with the domestic market when IS strategies are adopted or intensified than they can be for moving toward EP. The reason for couching the discussion in terms of a move toward EP is that most stabilization efforts, discussed below, entail a reduction, or an attempted reduction, in the extent of bias toward IS.

8. If the existing bias of the regime has been relatively shortlived at the time of the policy shift, it is possible that excess capacity might exist in EP 7 ines to pick up the slack from reduced IS activities. That outcome is less likely, the longer IS policies have been in place. A more frequent pattern is that IS industries find that they can cover marginal costs in exporting out of existing capacity once incentives change. The commodity composition of exports in the year or two after shifting strategies therefore may bear little relation to the longer-run mix of exports.

9. All three have reverted to relatively high inflation rates in the mid-1970s, and seem to be encountering much more difficulty at the present time in reducing their inflation rates than they had earlier experienced.

10. See Jere R. Behrman, Foreign Trade Regimes and Economic Development: Chile (Columbia University Press for the National Bureau of Economic Research, 1976) for a full account. 
11. Carlos Diaz-Alejandro, Foreign Trade Regimes and Economic Development: Colombia (Columbia University Press for the National Bureau of Economic Research, 1976).

12. It is important to recognize that foreign lending and aid, motivated by prospects of a reasonable rate of return or for development purposes, can sustain a current account deficit and contribute, as long as it lasts, to development objectives. In those cases, the current account deficit is offset by "autonomous" capital inflows. Deficits, as used in the text, refer to payments imbalances in which the desired transactions by individuals result in an excess demand for foreign exchange which must be met by the authorities by running down their reserves or seeking foreign financing which they would not seek simply for long-run developmental objectives. While the distinction is conceptually clear, there are often significant difficulties in practice of identifying particular types of transactions as being "autonomous" and others as being "accommodating." In practice, however, few worry about the "deficit" of Korea, as the financing is motivated by long-term commercial prospects, while it is straightforward to identify countries whose borrowing needs originate from their efforts to sustain an infeasible exchange-rate. At the time of writing this paper, Turkey represents a classic case of a country attempting to maintain an unrealistic exchange rate, borrowing for that purpose in excess of the amount. she would otherwise borrow. It should be noted, however, that in an 
alternative economic context, Turkish net capital inflows might be much larger than they currently are. The reason, of course, is that commercial lending and investing has virtually ground to a halt as expectations of an exchange rate alteration lead potential creditors with commercial motivations to delay their activities.

13. There are exceptions, of course. Notable among them is the Korean case. The Koreans appear to have maintained quantitative restrictions upon import of luxury consumer goods which were not domestically produced. Interestingly, licenses to import those goods were awarded to exporters, thereby linking QRs (which were not intended as a balance of payments measure in the first place) to profitability of exporting.

14. This is becaluse the higher price of import-competing goods under QRs will likely pull some resources out of the home goods sector.

15. A regime is said to be more restrictive, the larger the aggregate value of premiums expressed as a percentage of the landed cost of the import bill.

16. This statement assumes that raising the price of foreign exchange is not accompanied by a sufficient increase in aggregate demand so that the domestic price level increases still further. Obviously, a devaluation of $x$ percent, followed by an increase in the domestic price level of ax, with a $>1$, will lead to a decline 
in the relative price of tradable goods and should intensify either the restrictiveness of the regime or the size of the deficit.

17. The empirical results from the Foreign Trade Regimes and Econonic Development project tended to confirm the results. See Chapter 8 of my Liberalization Attempts and the individual studies, especially Colombia and Chile, for analysis of this phenomenon.

18. If for example, surcharges on imports and export subsidies are removed simultaneously with the devaluation, the changes in the effective exchange rates perceived by producers and consumers will be considerably smaller than the size of the devaluation. It is usefu? to refer to "net devaluation" as being the change in the price of foreign excinange once account is taken of the removal of export subsidies, import surcharges, and the like.

19. Egon Sohmen, in "The Effects of Devaluation on the Price Level," Quarterly Journal of Economics, May 1958, made this point.

20. The difficulties are very real. Richard Cooper, in his "An Assessment of Currency Devaluation in Developing Countries," Chapter 13 of Gustav Ranis, Editor, Government and Economic Development (Yale University Press, 1971) documented these problems neatly. A sizable fraction of Finance Ministers at the time of devaluation have lost their jobs within 18 months afterwards. There is no doubt also that luck is an element. As Cooper showed, perhaps the 
best indicator of the likelihood of success is the quality of the harvest: a good harvest provides a buffer which makes the reallocation vastly easier. Of the 22 devaluations in the NBER project on Foreign Trade Regimes and Economic Development, in 15 cases the inflation in the ensuing two years was larger proportionately than was the initial devaluation. See my Foreign Trade Regimes and Economic Development, pp. 82-83 and Table 5-3.

21. Diaz-Alejandro, op.cit, pp. $237 \mathrm{ff}$.

22. Many Latin American programs, especially those of Chile and Argentina, seem to have been geared primarily toward inflation.

23. Turkey and India are examples of this type.

24. See Al Fishlow, "Foreign Trade Regimes and Economic Development: Brazil," paper prepared for Bogota Seminar, April 1975, mimeo.

25. This clearly happened in Turkey following the 1958 devaluation.

26. For an analysis of the political implications of donor behavior with respect to one devaluation, see Jagdish Bhagwati and T. N. Srinivasan, Foreign Trade Regimes and Economic Development: India (Columbia University Press for the NBER, 1975), Chapter 10. Diaz-Alejandro, op. cit., reports that, prior to undertaking its own liberalization program in 1967, the Colombian president even went on television to state that he would not abide by the wishes of Colombia's creditors! 
27. Thomas Reichman and Richard Stilison, "Experience with Programs of Balance of Payments Adjustment: Stand-By Arrangements in the Higher Tranches, 1963-72," IMF Staff Papers, Vol. 25, 2, p. 297.

28. Liberalizing the regime cannot be carried very far without increasing the flow of imports. In the short run, that can usually be achieved only when financed by foreign credits, which are discussed below.

29. Removal or reduction of guarantee deposit requirements can have a significant effect on the money supply. For this reason, it sometimes makes sense to provide for their gradual removal, rather than to abandon them at the time of devaluation.

30. See Jose Carvalno and Claudio Haddad, "Brazil," Chapter . 2 of Anne 0. Krueger, Hal B. Lary, Terry Monson, and Narongchai Akrasanee, Editors, Trade and Employment in Developing Countries -Strategies and Results in Ten Countries (University of Chicago Press for the NBER), forthcoming.

31. See my Liberalization Attempts, Chapter 11 , for the statistical evidence on this point for a pooled time-series crosssection of devaluations in the NBER project countries. See also Bela Balassa, "Exports and Economic Growth: Some Further Evidence," Journal of Development Economics, June 1978. 
32. In some instances, expectations of an exchange-rate alteration induce exporters to withhold their goods and importers to stock up. Reverse flows after devaluation can then finance increased imports. While that can happen, it is difficult to rely on it. 


\section{Bibliography}

Balassa, Bela, "Exports and Economic Growth: Some Further Evidence," Journal of Development Economics, (June 1978).

Baldwin, Robert, Foreign Trade Regimes and Economic Development:

Philippines. New York: Columbia University Press for the National Bureau of Economic Research, 1975.

Behrman, Jere R., Foreign Trade Regimes and Economic Development:

Chile. New York: Columbia University Press for the NBER, 1976. Bhagwati, Jagdish and T. N. Srinivasan, Foreign Trade Regimes and Economic Development: India. New York: Columbia University Press for the NBER, 1975. Carvalho, Jose, and Claudio Haddad, "Brazil," Chapter 2 in Anne 0. Krueger, Ha] B. Lary, Terry Monson, and Narongchai Akrasanee, Editors, Trade and Employment in Developing Countries -Strategies and Results in Ten Countries. Chicago: University of Chicago Press for the NBER, forthcoming.

Cooper, Richard, "An Assessment of Currency Devaluation in Developing Countries," in Gustav Ranis, Editor, Government and Economic Development. New Haven: Yale University Press, 1971.

Diaz-Alejandro, Carlos, Foreign Trade Regimes and Economic Development:

Colombia. New York: Columbia University Press for the NBER, 1976. Fishlow, Al, "Foreign Trad Regimes and Economic Development: Brazil," paper prepared for Bogota Seminar, Apri1, 1975.

Krueger, Anne 0., Foreign Trade Regimes and Economic Development:

Liberalization Attempts and Consequences. Cambridge: Ballinger

Press for the NBER. 
Michaely, Michael, Foreign Trade Regimes and Economic Development: Israel. New York: Columbia University Press for the NBER, 1975. Reichmann, Thomas and Richard Stillson, "Experience with Programs of Balance of Payments Adjustment: Stand-By Arrangements in the Higher Tranches, 1963-72." IMF Staff Papers, Vol. 25, 2, p. 297.

Sohmen, Egon, "The Effects of Devaluation on the Priceheird," Quarterly Journal of Economics, (May 1958). 